\title{
Proposed new postural positions oral cleaning in babies
}

\section{Proposta de novas posições posturais para a limpeza bucal de bebês}

Rise Consolação luata Costa Rank ${ }^{1}$, Joana Estela Rezende Vilela², Luciana Marquez ${ }^{3}$, Marília Pantoja Soares Silva ${ }^{4}$, Tatiane Lourenço de Sousa ${ }^{5}$, Wataro Nelson Ogawa 6

\section{ABSTRACT}

The objective of this study was to propose to mothers two new postural positions to assist in the oral cleaning of infants up to 8 months of age and to verify their acceptance. The sample consisted of 38 mothers and their infants who participated in a program to promote oral health for children. The study consisted of 2 residential visits. In the first, a questionnaire was filled out by the mothers in order to know the habitual position in which the mother performed the hygiene of the baby's oral cavity and there was orientation with the new proposals for oral cleaning (Positions 1 and 2). After 30 days, there was the return to verify which of the positions the mother preferred. Although the mothers received information about the baby's oral health, they weren't told about an ideal postural position to perform oral cleaning. The diaper $(86.8 \%)$ was the most used instrument, $31.5 \%$ found it difficult to clean the child's mouth, in which the majority of mothers reported being afraid of hurting the child during hygiene (91.6\%). Position 1 was preferred for oral hygiene $(p=0.01)$, and of the reasons pointed out, proposal 1 was the easiest one $(p=0.04)$. All mothers adopted one of the new positions presented and position 1 was the most selected for oral hygiene in children.

Keywords: Oral hygiene. Child. Health Promotion

\section{RESUMO}

O objetivo deste estudo foi propor às mães duas novas posições posturais para auxiliar na limpeza bucal de bebês com até 8 meses de idade e verificar sua aceitação. Metodologia: A amostra foi constituída de 38 mães e seus bebês, participantes de Programa de promoção em saúde bucal infantil. A pesquisa consistiu em 2 visitas residenciais, na primeira houve preenchimento do questionário pelas mães para conhecer a posição habitual em que a mãe realizava a higienização da cavidade bucal do bebê e houve orientação com as novas propostas posturais de limpeza bucal (Posição 1 e 2). Após 30 dias houve o retorno para verificar qual das posições a mãe preferiu. Resultados: Apesar das mães terem recebido informações sobre saúde bucal do bebê, elas não foram orientadas a respeito de uma posição postural ideal para realizar limpeza bucal. A fralda (86,8\%) foi o instrumento mais utilizado, 31,5\% achou difícil limpar a boca da criança, em que a maioria das mães relatou ter medo de machucar a criança durante a higienização (91,6\%). A posição 1 foi a preferida para a higienização bucal $(p=0,01)$, e dos motivos apontados, a proposta 1 foi a mais fácil delas $(p=0,04)$. Conclusão: Todas as mães adotaram uma das novas posições apresentadas e a posição 1 foi a mais selecionada para higienização bucal infantil.

Palavras-chave: Higiene bucal. Criança. Promoção da saúde.
${ }^{1}$ DDs Pediatric dentistry. UNIRG University, Gurupi, Brazil .

E-mail: riserank@yahoo.com.br

${ }^{2}$ MS. Department of Public Health, UNIRG University .

${ }^{3}$ MS. Stomatology, Ceulp/ULBRA University Center .

${ }^{4}$ Es. Management in Public, Collective and Family Health. UNIRG University .

${ }^{5}$ Graduated on Dentistry. UNIRG University.

${ }^{6}$ Ph.D. in Science. UNIRG University 


\section{INTRODUCTION}

Over the years, dentistry has been changing in terms of prevention and promotion of oral health. The approach of the pregnant woman by professionals in the area to prepare for the arrival of the baby is extremely important for the awareness of preventive-educational methods regarding exclusive breastfeeding during the first six months of life, as well as guidance and motivation of the child's oral hygiene habit (HOROWITZ et al., 2017).

Current research suggests that Early Childhood Caries (ECC) has important etiologic bases during the first year of life, and that lack of knowledge about disease progression prevents the effective and early identification of at-risk children (LEONG et al., 2013). Thus, in order to accustom the child to the manipulation of the mouth and the sensation of "clean mouth", the first care should be started early, not only to prevent diseases of the oral cavity, but mainly to create the habit (GUARIENTI et al., 2009; SZPILMAN et al., 2012). Few studies have been conducted on edentulous children, but it is known that there is a rich bacterial community in the buccal cavity before the dental eruption, because of the mixed diet (CEPHAS et al., 2011). The etiology of childhood dental caries involves a complex interplay of microbial, genetic, biochemical, social and physical environmental, and health-influencing behavioral factors (ALBINO et al., 2016).

The public program for the Promotion of Oral Health in Children (POHC), called "Baby's mouth", was implemented in 2010 in the city of Gurupi, Tocantins State, northern region of Brazil, in partnership with the City Hall and UnirG University Center. This program guides mothers for baby oral hygiene. Following national and international oral health guidelines: from birth to the first dental eruption, the gums are cleaned twice a day with moist gauze or special soft cloth diaper; after eruption of the first primary tooth, brushing teeth after meals, putting only a little toothpaste (1000 ppmf) to minimize the risk of ingestion, but this program did not orient the mothers on a suitable postural position for the hygiene of the mouth of a newborn baby up to 8 months (AMERICAN ACADEMY ON PEDIATRIC DENTISTRY, 2008; MARTINS-JUINNIOR et al., 2013; CAPASSO et al., 2016). The way the mother will approach this child for hygiene will be the starting point for the first care with oral health. Thus, the POHC team composed of dentists, nurses, medical students, speech therapists and physiotherapists studied two posture positions adequate to provide safety and comfort for the baby and his mother. We believe that these positions provide better access to the baby's oral cavity so that the cleaning process is not traumatic to the mother / 
child. Therefore, this study aimed to investigate the introduction of two new postural positions and verify the acceptance by the mothers.

\section{METHODOLOGY}

A cross-sectional and observational study by a multiprofessional and interdisciplinary team, conducted in the Legal Amazon region covering the micro region of Bananal Island, within the framework of the public health network of Gurupi (TO), in the city of Gurupi, Tocantins, Brazil. This research was submitted and approved by the Committee of Ethics in Research with human beings of the UnirG University Center. CAAE: 32671414.4.0000.5518.

The sample size calculation was based on 180 mothers that enrolled children from 1 to 8 months in 2015 . The visit was domiciled, and therefore $20 \%$ of the total sample was selected. The 38 mothers were approached and invited to participate in the research in order of arrival to attend the program (August to September), which happened every week in different Basic Health Unit (BHU). With the acceptance of the mother, the researchers clarified the methodology and the objectives of the study, having the right of nonparticipation without any prejudice regarding dental care in the program attended. In addition, the person responsible signed a free and informed consent form for participation in the research.

The inclusion criterion included mothers with children up to 8 months, beginning in the "Boquinha do Bebê" program, of both sexes, without distinction of race or color, who accepted the visit of the researchers in their homes. The exclusion criteria were: mothers who did not know how to read; children in which caregivers were not mothers; mothers whose children were carriers of chronic and contagious acute infections in medical treatment and children with motor and / or skeletal anomalies.

The research was carried out in the mothers' homes. Step 1: with prior appointment to visit, where they filled out a questionnaire with multiple choice questions about the baby's oral health, importance and difficulties encountered during hygiene. Soon after, a photographic picture was taken of the habitual position in the place where the mother performed the hygiene of the baby's oral cavity, for that, the researchers asked the mother to perform the cleaning where she usually did. The researcher was responsible for sending a copy of the photograph online (via e-mail) or printed, if the parents requested. Soon after, the team guided the mother with two new proposals for postural cleaning of the mouth, through images in the poster, with the primary demonstration by an assistant with doll use. 
Position 1: baby fitted in leg / knee position folded; and position 2: baby accommodated in both legs supported on a chair (Figure 1). The mothers observed the demonstration and experimented with two positions with the use of the doll. From that day, all the mothers were left to hold one of these positions in their babies for oral hygiene, but if they did not feel comfortable, they could use the position they used previously. Step 2: consisted of a return to the home 30 to 40 days later to verify which of the techniques the mother preferred, position 1, 2 or maintained the usual (Figure 1). The preferred position was photographed and the mother answered questions addressing the new positions.

Figure 1: Images in the poster showing two new postural positions for infants' oral cleaning.

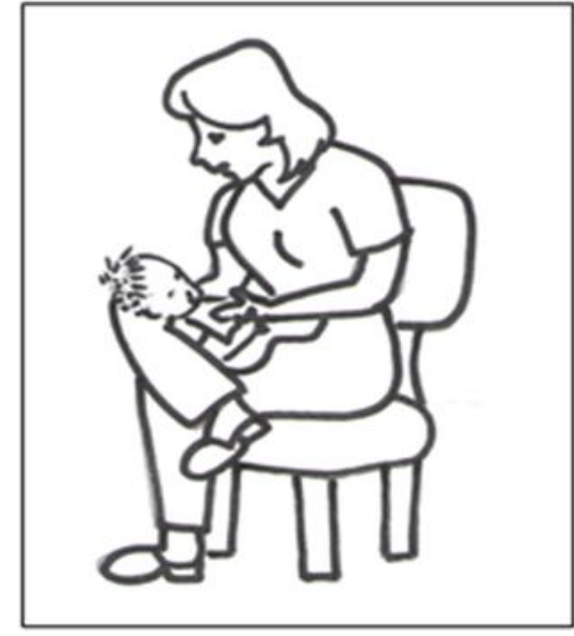

Position 1: baby fitted in leg / knee position folded

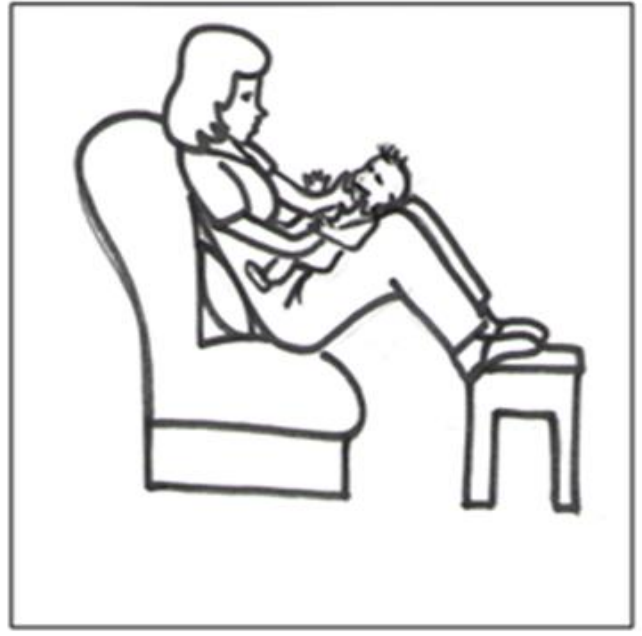

Position 2: baby accommodated in both legs supported on a chair

\section{RESULTS}

In this parametric quali-quantitative analysis, the results were analyzed using the Epi Info software version 3.5.2. Firstly, the frequency analysis of some data for the description and characterization of the sample was performed. The chi-square test, with a significance level of $5 \%$ was established to verify the association of the variables.

Based on the analysis of the results collected in the sample of 38 mothers and their babies, there was a predominance of females among infants (Table 1). As for the average age of the mothers interviewed, $28.5 \%$ were between 15 and 20 years old and $71.4 \%$ were older than 20 years of age. 
Table 1: Distribution of characteristics of the study sample (mothers and children).

\begin{tabular}{|c|c|}
\hline $\begin{array}{l}\text { Children } \\
\text { Age in months }\end{array}$ & $3 \pm 1.69$ \\
\hline \multicolumn{2}{|l|}{ Children's Gender } \\
\hline $\begin{array}{l}\text { Female } \\
\text { Male }\end{array}$ & $\begin{array}{l}20(52.6 \%) \\
18(60.8 \%)\end{array}$ \\
\hline Mother's age & $25 \pm 7.06$ \\
\hline \multicolumn{2}{|l|}{ Mother's education level (yrs) } \\
\hline$\leq 8$ & $13(3 ., 2 \%)$ \\
\hline$>8$ & $25 \quad(65.7 \%)$ \\
\hline \multicolumn{2}{|l|}{ Living with a partner } \\
\hline Yes & $24(63.1 \%)$ \\
\hline No & $14(36.8 \%)$ \\
\hline \multicolumn{2}{|l|}{ Family income } \\
\hline Less than one minimum wage & $3(7.9 \%)$ \\
\hline One minimum wage & $21(55.2 \%)$ \\
\hline Two minimum wage & $12(31.5 \%)$ \\
\hline Three minimum wage & $2(5.2 \%)$ \\
\hline \multicolumn{2}{|l|}{ Number of children } \\
\hline 1 & $11(28.9 \%)$ \\
\hline 2 & $9(23.6 \%)$ \\
\hline 3 & $11(28.9 \%)$ \\
\hline 4 & 7 (18.5\%) \\
\hline \multicolumn{2}{|l|}{$\begin{array}{l}\text { Did you plan to breastfeed your } \\
\text { child? }\end{array}$} \\
\hline Yes & $35(92.1 \%)$ \\
\hline No & $3(7.9 \%)$ \\
\hline
\end{tabular}

When asked if they had received guidance regarding the importance of cleaning the baby's mouth from the program, and if they learned to do the hygiene, all mothers said yes. Regarding the periodicity of cleaning of the baby's mouth, most of the mothers did the hygiene once or 2 times a day. There were mothers who even when clarified about the importance of the baby's oral hygiene, still could not clean the baby's mouth (Table 2).

Table 2: Distribution of questionnaire responses applied to mothers in number and percentage found.

\section{Questions}

How many times a day do you clean the baby's mouth?

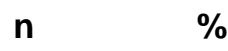

$14 \quad 36.8$

$11 \quad 28.9$ 


$\begin{array}{rrr}3 & 5 & 13.3 \\ \text { I can not } & 8 & 21 \\ \text { Total } & 38 & 100\end{array}$

What period(s) of the day do you clean your baby's mouth? (You can check more than one alternative):

$\begin{array}{rll}\text { Morning } & 23 & 60.5 \\ \text { Afternoon } & 21 & 55.2 \\ \text { Evening } & 13 & 34.2\end{array}$

What do you use to clean the baby's mouth? (You can check more than one alternative)

$\begin{array}{rrr}\text { Tooth brush } & 4 & 10.5 \\ \text { Cloth Diaper } & 30 & 79 \\ \text { Gauze } & 5 & 13.5 \\ \text { rstall or other } & 2 & 5.2\end{array}$

Fingerstall or other
do bebê de 0 a 8 meses?

Alguém te ensinou uma postura para limpar a boca do bebê de 0 a 8 meses?

\section{0}

$\begin{array}{rrr}\text { Sim } & 1 & 2.6 \\ \text { Não } & 33 & 86.8 \\ \text { Não lembro } & 5 & 13.2 \\ \text { Total } & 38 & 100\end{array}$

How does the baby reach when you clean the mouth?

$\begin{array}{lll}\text { Calm } & 13 & 34.2\end{array}$

Agitated but cooperative $\quad 19 \quad 50$

$\begin{array}{lll}\text { Agitated but not cooperative } & 6 & 15.8\end{array}$

Total $\quad 38 \quad 100$

Does your child have teeth?

$\begin{array}{rrr}\text { Yes } & 9 & 23.6 \\ \text { No } & 29 & 76.3\end{array}$

Do you, as a mother, find it hard to clean the baby's mouth?

$\begin{array}{rrr}\text { Yes } & 12 & 31.5 \\ \text { No } & 26 & 68.5 \\ \text { Total } & 38 & 100\end{array}$

If you answered yes, answer why (you can check more than one alternative) - (n-12)

$\begin{array}{rrr}\text { I am afraid I might hurt him } & 11 & 91.6 \\ \text { He will not let me do it } & 3 & 25 \\ \text { I can not find a proper position } & 2 & 16.6 \\ \text { I find it difficult cleaning the baby's mouth } & 5 & 41.6\end{array}$

The cleaning instrument most used by the mothers in the oral hygiene of the baby was the diaper followed by the gauze. According to the mothers, this cleaning process was preferably performed in the morning. Of the mothers who received postural orientation to clean the baby, it was reported that it was her mother who taught her (grandmother).

Regarding the behavior of the baby during oral cleaning, half of the mothers described their babies as agitated, but collaborated during the hygiene process. Of the mothers who found it difficult to clean the child's mouth (31.5\%), most reported being afraid of hurting the child during hygiene $(91.6 \%)$. 
In table 3, two positions were more common for oral hygiene, the position where the mother was sitting with the baby lying crossed in her lap (75\%), and the second position was with the child lying on a bed or sofa (23\%). From these positions, there was a significant difference in the relationship between the position and the difficulty found for oral cleaning, demonstrating that mothers felt greater difficulty when the child was lying on the bed or sofa $(p=0.01)$.

Table 3: Distribution in numbers of the habitual hygiene position regarding the difficulty found by the mother in the act of cleaning.

\begin{tabular}{c|cccc}
\multirow{2}{*}{ DIFFICULTY } & \multicolumn{2}{c}{ HABITUAL HYGIENE POSITION } & TOTAL & $\boldsymbol{p}$ value \\
\cline { 2 - 5 } & Lying down & On the lap & & \\
YES & 6 & 6 & 12 & $* 0.01$ \\
NO & 3 & 23 & 26 & \\
TOTAL & 9 & 29 & 38 & \\
$*$ Chi-square test with a significance level of $p<0.05$. & &
\end{tabular}

Of the 38 mothers oriented with the new postural positions, all of them after 30 days claimed to have chosen one of them, in which the majority chose position 1 , and only nine preferred position 2 to perform the oral cleaning of the babies (Table 4). The reason for the preference showed a very significant result in the practicality of cleaning the mouth of the baby for position $1(p<0.004)$.

Table 4: Distribution in number and percentage of the preference of the new postural positions of oral hygiene chosen by the mothers, with option of more than one alternative.

\begin{tabular}{|c|c|c|c|c|}
\hline \multirow[t]{2}{*}{ Reasons for preference } & \multicolumn{2}{|c|}{ Position 1} & \multicolumn{2}{|c|}{ Position 2} \\
\hline & $\mathrm{N}$ & $\%$ & $\mathrm{~N}$ & $\%$ \\
\hline Easier to apply & 22 & 75.8 & 1 & 11.1 \\
\hline Faster and the child allows & 2 & 6.8 & 3 & 33.3 \\
\hline More comfortable for the baby & 9 & 31 & 4 & 44.4 \\
\hline More comfortable for the mother & 8 & 27.6 & 5 & 55.5 \\
\hline Can clean the baby's mouth better & 17 & 58.6 & 1 & 11.1 \\
\hline \multirow[t]{3}{*}{ Another reason } & & & 1 & 11.1 \\
\hline & 58 & & 15 & \\
\hline & \multicolumn{4}{|c|}{$p<0,004^{*}$} \\
\hline
\end{tabular}


The great challenge of public policies is to work on health promotion and disease prevention in the community, knowing that the best way is through education and motivation to develop correct habits. These measures reduce costs in the public health system and are more economical (ZWICKER et al., 2016). Prioritization of educational actions in primary health care within families has a great impact on the development of oral health habits of children, achieving a better quality of life (SCHOR, 2003).

Oral health can not be seen as separate from systemic health, so dental care goes beyond tooth preservation, but also aims to promote health in all its aspects. Early childhood caries (ECC) is a public health problem and requires involvement of all health care providers who provide care for children. Therefore, we must establish a partnership with the family to prevent and reduce caries risk factors (SCHROTH et al., 2016). To avoid tooth susceptibility to caries disease, appropriate oral hygiene should be initiated before the first tooth erupts and continue until the child is able to act independently (KAGIHARA et al., 2009). Prevention is cheap, but it requires the efforts of the whole family, in which it is often unaware of the consequences that caries can have on the child's quality of life (LOSSO et al., 2009; ZWICKER et al., 2016).

Currently, there are several questions regarding the ideal moment to start caring for the oral hygiene of the child, since caries disease is multifactorial caused by dysbiosis and sucrose intake,16 and caries disease can only occur after tooth eruption, however, it is known that there are other oral diseases and the importance of early cleansing serves to introduce and motivate the child to these good hygiene habits from birth (GUARIENTI et al., 2009).

The POHC seeks, in an interdisciplinary way, to motivate women from gestation to this cleaning, but there was an impasse when she realized that the team asked for the mother to be cleaned because she was not taught a standard or adequate position due to the lack of scientific evidence. Neves et al. (2017) encourage cleaning the gums of still-toothless babies on the adoption of correct daily habits in their routines, although the American Academy of Pediatric Dentistry (2012) recommends that if the infant performs exclusive breastfeeding, parents should not begin to clean their mouths before the primary teeth appear. By recommending oral hygiene since the birth of the child, it is considered that there is a considerable variation in the time of the dentition. There is no exact prediction of this event. In general, most children begin teething at six months. However, some children begin teething before the age of four months (1\%) or after 12 months of age (1\%). Some children 
are born with deciduous teeth (birth teeth), that occurs in about one in 2000-6000 live births. It is also possible to begin teething irruption in the first four weeks of age, considered as neonatal teeth (IRVING, 2013).

The longitudinal study by Cunha et al. (2009) evaluated the behavior of children from the first to the third year of life during ten dental visits, with an average period of 20 months for completion of the appointments. The results support the concept that patients' behavioral reactions undergo a maturation process during the first three years of life, which can be divided into three phases. In the first phase (corresponding to the first year of life), the patient exhibits a cooperative behavior regarding dental procedures. At this stage, the baby strongly manifests one of the types of global response to the complex of stimuli offered by the environment, which is called affectionate reaction. The child tries to establish a positive adaptation to the environment. In the second and third phases, the infant's motor skills mature and increase the child's non-cooperation, with more crying, closing of the mouth, tongue action and use of other parts of the body that have acquired a notion of movement, such as the arms. In this study, the mothers reported having no difficulties in cleaning the child's mouth at home, probably because it was in the first stage described.

Creating an early healthy habit in the child is much easier for the parents than changing behavior already inserted in the family experience (ALBINO et al., 2016). Stimulation of the child's mouth with oral cleaning promotes the entry of foreign objects into his mouth, such as gauze or a brush, and will be a training so that the baby gets accustomed to the good habit of hygiene and oral cleaning. Thus, the child becomes accustomed to the manipulation of hygiene in the mouth, not hindering the professional in the clinical examination and necessary interventions when visiting him (ZWICKER et al., 2016).

From the moment the child is born, there is an interdependence with his environment, having in the parents or responsible the key role of this biopsychosocial development (QUOCK, 2015). Despite the low percentage of children found to be "agitated" and "noncompliant" (15\%), the mother was probably not able to enter the habit because of lack of position or insecurity in the hygiene technique.

In order for good hygiene to be carried out, it is of paramount importance to use an instrument of cleaning ideal for each age group. According to this study, the diaper (81\%) was the cleaning instrument most used by mothers, followed by gauze (13.5\%). The diaper and gauze were the ideal instruments for cleaning the baby's mouth in the care protocol 
(MOURA et al., 2006). Soares et al.(2013) reported that although dentists recommend oral hygiene in infants even before teeth erupt, these specific recommendations are still not performed by pediatricians. Thus, if mothers do not have contact with dentist soon after birth, they may not receive this guidance.

In this study, some children who have had teeth were not getting brushing, only four of them (10.5\%). Probably they were cleaning without toothbrush by ignoring the importance of the technique when you have teeth. $21 \%$ of the mothers, even though they received the guidelines, still did not perform cleaning of the baby's mouth, which may be due to doubts that promote fear of error or injury to the child. In this way, a multilevel approach is necessary from the time factor notion of differential susceptibility of each child, resilience to new habits, since there are multiple factors that cause oral diseases (FISHER-OWENS et al., 2007).23

No information was available in the literature regarding postural positions for the oral hygiene of babies from 0 to 8 months. Ramos-Gomez (2005) suggests a knee to knee position for children from 6 months to 3 years of age. Children over 3 years old can sit on the caregiver's lap or alone in a chair for hygiene. For children older than 3 years, the child stands in front and with his back to his mother, puts his head against it. The mother uses her left hand to hold and stabilize the jaw and with the fingers of this hand, moves her lips and cheeks, her right hand wields the brush, performing the movements. The jaw should be in a horizontal plane.

According to Ribeiro et al. (2005), the knee-knee position is the most practiced in dentists' offices, allowing a better position to examine children up to 2 years of age. It is suggested that the father or mother holds the child in the lap, looking at the father or mother while the child puts his head on the dentist's leg. This position allows the child to maintain eye contact with the parents while the dentist has access to the mouth, in this way the child feels safe allowing the dentist to promote all due care to the child. This technique is not commonly used at home by mothers in their daily lives since they need the assistance of another person. For Szpilman et al. (2012), the relevant care with the oral health of the baby is performed exclusively by the mothers, and the father does not participate in providing the necessary help for the hygiene of the baby's mouth. Thus, the knee-knee technique becomes infeasible to be practiced by mothers at home without the help of another person.

It was observed during this study that the mothers sought, from basic day-to-day criteria, to find ways to perform hygiene, but in the first difficulty, they failed to perform 
frequently. The number 1 position, tested in this research was the one that most pleased the mothers for dispensing any apparatus or help, reinforcing the information that mothers care about the oral hygiene of their children. In position number 2 , it is necessary to use a footrest, restricting the places where the mothers can perform the cleaning of the baby's mouth. Of these two positions, one of the mothers reported having selected position 2 because she was "fat" and unable to perform position 1.

Analyzing the lack of information available in the literature regarding postural positions for the oral hygiene of babies from 0 to 8 months of age and the difficulties encountered by the mothers participating in the baby program, this study provided two techniques that were beneficial for both mother / child. It is known that every learning process involves difficulties, so these authors believe that these positions should be oriented even in the gestation so that, as soon as the baby is born, the mother can already initiate oral cleaning knowing a postural position that allows greater comfort and security.

\section{CONCLUSION}

This research made it possible to observe the existing gap in oral health care programs, since the literature consulted did not present pertinent studies to indicate ideal positions that provide comfort, safety and practicality of hygiene by the mother to the baby from 0 to 8 months. Thus, mothers empirically select postures that they believe are most comfortable with their children. After orientation of positions for the baby's oral hygiene, the mothers preferred to place the baby in position in the folded leg / knee position, conferring position1 as the best.

\section{REFERENCES}

ALBINO, J.; TIWARI, T. Preventing Childhood Caries: A Review of Recent Behavioral. Research Journal of Dental Research, v. 95, n.1, p:35-42, 2016.

AMERICAN ACADEMY OF PEDIATRIC DENTISTRY. Guideline on Infant Oral Health Care, v.31, n.6, p: 95-99, 2012.

AMERICAN ACADEMY ON PEDIATRIC DENTISTRY. Policy on early childhood caries (ECC): Classifications, consequences, and preventive strategies. Pediatr Dent, v.30, n.7, (Suppl), p:40-43, 2008.

CAPASSO, F.; VOZZA, I.; CAPUCCIO, V.; VESTRI, A.R.; POLIMENI, A.; OTTOLENGHI, $\mathrm{L}$. Correlation among periodontal health status, maternal age and pre-term low birth weight. Am. J. Dent., v.29, p: 197-200. 2016. 
CEPHAS, K.D.; KIM, J.; MATHAI, R.A.; BARRY, K.A.; DOWD, S.E. Comparative analysis of salivary bacterial microbiome diversity in edentulous infants and their mothers or primary care givers using pyrosequencing. PLoS ONE, v.6, n.8, p: e23503, 2011. doi:10.1371/journal.pone.0023503.

CUNHA, R.F.; ZAZE, A.C.S.F.; VIEIRA, A.E.M.; MELHADO, F.L.; SUNDEFELD, M.L.M.M. Longitudinal behavioral analysis during dental care of children aged 0 to 3 years. Braz. Oral Res., v.23, n.3, p: 302-306, 2009. http://dx.doi.org/10.1590/S180683242009000300013

FISHER-OWENS, S.A.; GANSKY, S.A.; PLATT, L.J.; WEINTRAUB, J.A.; SOOBADER, M.J.; BRAMLETT, M.D.; NEWACHECK, P.W. Influences on Children's Oral Health: A Conceptual Model Pediatrics. American Academy of Pediatrics, v.120, n.3, p: e510-520, 2007.

GUARIENTI, A.C.; BARRETO, V.C.; FIGUEIREDO, C.M. Parents' and Caregivers' Knowledge of Oral Health in the Early Childhood. Pesq. Bras.Odontoped. Clinlntegr, v.9, n. 3; p: 321-325, 2009.

HOROWITZ, A.M.; KLEINMAN, D.V.; CHILD, W.; RADICE, S.D. Perceptions of Dental Hygienists and Dentists about Preventing Early Childhood Caries: A Qualitative Study. Journal of Dental Hygiene, v.91, n.4, p:29-36. 2017.

IRVING, J. In infants, teething is the process in which deciduous teeth (sometimes known as milk teeth or baby teeth) emerge through gums. This is a normal physiological process. Independent health visitor. May 2013. https://www.nursinginpractice.com/article/teething-pain-babies

KAGIHARA, L.E.; NIEDERHAUSER, V.P.; STARK, M.; FISHER-OWENSLE, PLATT, L.J.; et al. Assessment, management, and prevention of early childhood caries. Journal of the American Association of Nurse Practitioners, v.21, n.1, p:1-10. 2009.

LEONG, P.M.; GUSSY, M.G.; BARROW, S.L.B.; SILVA-SANIGORSKI, A.; WATERS, E. A systematic review of risk factors during first year of life for early childhood caries. International Journal of Paediatric Dentistry, v. 23, p: 235-250. 2013.

LOSSO, E.M.; TAVARES, M.C.R.; SILVA, J.Y.B.; URBAN, C.A. Severe early childhood caries: an integral approach. J. Pediatr., v.85, n.4, p: 295-300. 2009.

MARTINS-JUINIOR, P.A.; VIEIRA-ANDRADE, R.G.; CORRÊA-FARIA, P.; OLIVEIRAFERREIRA, F.; MARQUES, L.S.; RAMOS-JORGE, M.L. Impact of early childhood caries on the oral health-related quality of life of preschool children and their parents. Caries Res., v.47, p: 211-218. 2013.

MOURA, L.F.A.D.; MOURA, M.S.; TOLEDO, O.A. Dental caries in children that participated in a dentistry providing mother and child care. J. Applied Sci., v.14; n.1, p: 53-60, 2006.

NEVES, T.; RANK, R.C.I.C.; GIMENEZ, T.; OLEGÁRIO, I.C.; CALVO, A.F.C.; TELLO, G.; IMPARATO, J.C.P. Behavioral analysis of Brazilian children participating in the "Baby's Little Mouth Program" at Gurupi-Tocantins. ODONTOLOGÍA, v.19, n.1, p:122134. 2017. 
QUOCK, R.L. Dental Caries: A Current Understanding and Implications. Journal of Nature and Science, v.1, n.1, p: e27, 2015.

RAMOS-GOMEZ, F.J. Clinical considerations for an infant oral health program. Rev. Compendium, v.26, n.5, p:17-23, 2005.

RIBEIRO, A.G.; OLIVEIRA, A.F.; ROSENBLATT, A. Early childhood caries: prevalence and risk factors in 4-year-old preschoolers in João Pessoa, Paraíba, Brasil. Cad. Saúde Pública, v.21, n.6, p:1695-1700, 2005.

SCHOR, E.L. Family pediatrics: report of the Task Force on the Family. American Academy of Pediatrics Task Force on the Family. Pediatrics, v.111, n.6, p:1541-1571, 2003.

SCHROTH, R.J.; NDAYISENGA, S.; GUENTHER, K.; MARCHESSAULT, G.; PROWSE, S.; HAI-SANTIAGO, K.; et al. Parents' and caregivers' perspectives on the Manitoba Dental Association's Free First Visit program. Journal of Public Health Dentistry, v.76; n.3, p: 206-212. 2016.

SOARES, I.M.V.; SILVA, A.M.R.B.; MOURA, L.F.A.D.; LIMA, M.D.M.; SOUSA-NÉTTO, O.B., et al. Conduct of pediatricians in relation to the oral health of children. Rev Odontol UNESP, v.42, n.4, p: 266-272, 2013.

SZPILMAN, A.R.M.; MARTINS, F.G.; JANTORNO, C.; COUTINHO JÚNIOR, E.Z.; et al; Condição de saúde bucal de crianças de zero a dois anos de idade inseridas na estratégia saúde da família (ESF)/ Oral health condition in zero to two years old children inserted in the family health strategy (FHS). Rev. Bras. de Pesquisa em Saúde. v.14, n. 1, p: 42-48, 2012.

ZWICKER, J.; DUDLEY, C.; EMERY, J.C. It's Not Just About Baby Teeth: Preventing Early Childhood Caries. SPP Briefing Paper, v.9, n.14, p: 1-19, 2016. 